Jurnal

Kardiologi Indonesia

J Kardiol Indones. 2015;36:168-74

ISSN $0126 / 3773$

\title{
Conotruncal Heart Defects
}

\author{
Herlina Dimiati, Silfia Yasmine Lubis
}

Bagian Ilmu Kesehatan Anak, Divisi Kardiologi Anak Fakultas Kedokteran UNSYIAH/BLUD RS. Zaenoel Abidin Banda Aceh
Conotruncal anomalies comprise a diverse group of congenital heart defects involving the outflow tracts of the heart and the great .They are a leading cause symptomatic cyanotic cardiac disease diagnosed in utero. Conotruncal anomalies can be diagnosed by prenatal echocardiography with a high degree of accuracy. The overall prognosis for fetuses with a conotruncal anomaly is poor

(J Kardiol Indones. 20 I5;36: I68-74)

Keywords: Conotruncal heart defects, prenatal echocardiography, prognosis 


\title{
Defek Konotrunkal Jantung
}

\author{
Herlina Dimiati, Silfia Yasmine Lubis
}

\begin{abstract}
Defek konotrunkal adalah penyakit jantung kongenital yang melibatkan saluran outflow dari jantung dan pembuluh darah besar. Defek konotrunkal menjadi penyebab utama pada penyakit jantung sianotik yang simptomatis yang dapat didiagnosis pada saat didalam kandungan Kelainan konotrunkal dapat dideteksi melalui fetal ekokardiografi dengan tingkat akurasi yang tinggi. Prognosis kelainan konotrunkal pada fetus buruk.
\end{abstract}

(J Kardiol Indones. 2015;36:168-74)

Kata kunci : defek konotrunkal, fetal ekokardiografi, prognosis

\section{Pendahuluan}

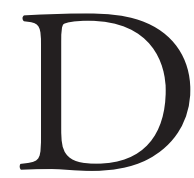
efek konotrunkal adalah penyakit jantung kongenital yang melibatkan saluran outflow dari jantung dan pembuluh darah besar. seperti, tetralogy of fallot, transposition of the great arteries, double - outlet ventricle, truncus arteriosus, type B interupted aortic arch, conal septal defect (subpulmonary ventricular septal defect I VSD), aorta - pulmonary window, dan malposisi secara anatomis dari arteri besar. Perkembangan abnormal

\section{Alamat Korespondensi:}

dr. Herlina Dimiati, Bagian Ilmu Kesehatan Anak, Divisi Kardiologi Anak Fakultas Kedokteran UNSYIAH/BLUD RS. Zaenoel Abidin Banda Aceh. E-mail: herlinadimiati@yahoo.com dari konus arteriosus (infundibulum) embrionik dan trunkus arteriosus dengan ventrikulo - arterial yang berhubungan dan abnormal seperti defek septal outlet, atau hipoplasia outlet, stenosis atau atresia. ${ }^{1}$ Defek konotrunkal menjadi penyebab utama pada penyakit jantung sianotik yang simptomatis dengan insidensi pada tahun pertama kehidupan sebanyak $20-30 \%$ dari seluruh anomali jantung. ${ }^{2}$

Banyak kasus defek konotrunkal dideteksi melalui ekokardiografi transtoraric dan transesofageal. Diagnosis dan prognosis dapat ditegakkan melalui pemeriksaan tersebut. Namun pemeriksaan terbaru adalah deteksi dini melalui fetal ekokardiografi untuk melihat diagnosis dan prognosis fetus yang akan dilahirkan. ${ }^{3}$

Penyebab defek ini gangguan multifaktorial dan kompleks. Sebanyak $75-85 \%$ pasien yang menderita sindroma delesi kromosom 22q11.2 akan memiliki 
defek konotrunkal jantung. Tidak ada fenotip yang konsisten yang berhubungan delesi kromosom $22 \mathrm{q} 11.2$ ini. Kasus ini juga berhubungan dengan inheritans mendelian seperti sindroma Digeorge/ velo - cardio - facial dan sindroma alegile, tetapi ada juga defek konotrunkal yang tidak melibatkan delesi kromosom 22q11.2. ${ }^{4}$

Terapi operatif menjadi pilihan pada defek ini. Namun terapi dini dapat meningkatkan mortalitas terutama pada defek konotrunkal dengan delesi kromosom $22 \mathrm{q} 11 .{ }^{5}$

\section{Tujuan tulisan ini adalah untuk membahas epidemiologi, faktor risiko, patofisiologi, diagnosis, talaksana dan prognosis dari defek kontrunkal}

\section{Defenisi}

Defek konotrunkal jantung adalah malformasi dari saluran outflow jantung, mungkin akibat dari gangguan saluran outflow jantung embrio, atau perkembangan yang terganggu pada lengkungan branchial dan arteri atau keduanya. Kelas dari defek ini termasuk: trunkus arteriosus, TOF, obstruksi lengkung aorta, DORV, dan TGA. Defek jantung ini sering berhubungan dengan sindrom digeorge, velocardiofacial, atau sindroma yang disebabkan delesi regio kromosom 22q11.5

\section{Tetralogi of fallot}

TOF adalah bentuk kelainan jantung bawaan sianotik yang paling umum dan terdiri dari $3.45-9 \%$ pasien dengan kelainan jantung bawaan.. Tidak adanya katup pulmonal terdapat pada $2.5 \%$ pasien TOF. Pada kasus ini, katup pulmonal rudimenter, biasanya kedua katup mengalami stenosis atau regurgitasi, arteri pulmonal secara signifikan mengalami dilatasi. Pasien dengan TOF menghadapi kemungkinan komplikasi residual dalam masa hidupnya, termasuk stenosis pulmonal, regurgitasi pulmonal, dilatasi dan disfungsi ventrikel kanan, ancaman aritmia dan kematian serangan jantung. ${ }^{2}$

\section{Trunkus Arteriosus}

Trunkus arteriosus merupakan penyakit jantung bawaan yang sangat tidak umum dan muncul pada $1.1-2.5 \%$ dari seluruh kasus, tanpa didominasi oleh perbedaan jenis kelamin. Pada defek ini terdapat trunkus ventrikel tunggal yang selalu dilatasi. Arteri pulmonal berasal bersamaan atau terpisah dari ujung trunkal. Katup trunkal biasanya abnormal, dengan dua sampai lima katup dan derajat stenosis dan regurgitasi yang bervariasi. Lengkung aorta (Aortic arch) yang terhambat biasanya diantara arteri karotis kiri dan subklavia. Defek ini bersamaan dengan DSV besar dikarenakan septum klonal yang pendek, dan bersamaan dengan katup atrioventrikular yang abnormal. Lengkung aorta kanan terdapat pada $\leq 35 \%$ pasien. $^{2}$

\section{Transposisi Arteri Besar/Transposition of great artery (TGA)}

TGA terdapat pada $5-7 \%$ dari semua penyakit jantung bawaan. Defek ini terdapat pada $60-70 \%$ jenis kelamin laki - laki. Diatas $80 \%$ kasus terdiri dari transposisi yang sederhana antara lain DSV atau septum intak, abnormal koroner, obstruksi outflow ventrikel kiri dan paten duktus arteriosus. ${ }^{2}$

\section{DORV (Double - outlet Right ventricle)}

Prevalensi DORV $\leq 1.5 \%$ dari seluruh penyakit jantung bawaan dan tidak ada perbedaan jenis kelamin. Kedua arteri besar berasal dari ventrikel kanan. Terdapat kontinuitas fibrous antara katup AV dan katup semilunar. Biasanya terdapat DSV, dimana outflow hanya terdapat pada ventrikel kiri. Arteri besar bisa saja terhubung secara normal, side - by - side, atau malposisi. ${ }^{2}$

\section{Dilatasi Lengkungan Aorta dalam defek konotrunkal}

Struktur abnormal dari dinding arteri besar seperti dilatasi, aneurisma dan ruptur terjadi pada paseien dengan defek konotrunkal. Ujung aorta yang dilatasi progresif telah dilaporkan hampir separuh dari TOF. ${ }^{2}$

\section{Epidemiologi}

Studi epidemiologi baru - baru ini telah menyimpulkan bahwa jumlah yang signifikan mengenai pasien dengan kelainan jantung bawaan berhubungan dengan sindrom genetikdan atau dengan malformasi ekstrakardial. Sindroma genetik terkadang berhubungan dengan 
fenotip spesifik kardial. Sehingga mungkin dapat mempengaruhi kondisi pasien dengan kelainan jantung bawaan secara klinis dan banyak kasus memberikan komplikasi pada prognosis penyakitnya. ${ }^{2}$

Sebanyak 10 - 15\% defek konotrunkal berhubungan dengan kejadian delesi pada kromosom 22q11. Studi di kuwait pada kasus trunkus arteriosus, empat diantaranya merupakan hasil perkawinan keluarga dekat, yakni perkawinan sepupu keturunan pertama. Keluarga yang dipantau tersebut memiliki kelainan yang melibatkan resesif dominan., 2,5

Mikrodelesi pada kromosom 22q11 terdapat pada 1:4000 kelahiran. Defek konotrunkal yang berhubungan dengan delesi tersebut termasuk lengkung aorta tipe B yang obstruksi, TOF dengan atresia pulmonal, dan trunkus arteriosus. Anomali lengkung dengan defek konotrunkal ditemukan lebih sering pada delesi 22q11 dibandingkan yang tidak memiliki delesi tersebut. Dari 90\% kasus, delesi 22q11 muncul secara sporadik, dan sekitar $10 \%$ terdapat hubungan keluarga dari orang tua yang terkena. Sehingga kemungkinan genetik dan atau faktor yang dimodifikasi secara epigenetik berperan dalam defek ini. ${ }^{1}$

Gambaran ekstrakardiak cukup luas pada anak anak yang memiliki defek konotrunkal dan mikrodelesi kromosom 22q11 lebih sering memiliki gambaran fasial dismorfik (low set ear, dysplastic flared pinna, short palpebral fissures, bulbous nasal tip, microstomia, high arched palate), jari panjang dan kurus dan hipokalsemia dibandingkan yang tidak memiliki delesi. Kombinasi dari gambaran ini berbeda dari setiap kasus. ${ }^{1,6}$

\section{Faktor Risiko}

Terjadinya defek konotrunkal berhubungan dengan kejadian prekonsepsi didalam janin antara lain nutrisi ibu saat hamil, kebiasaan merokok dan minum alkohol, penyakit ibu saat hamil seperti diabetes melitus, stress dan kebiasaan saat hamil, dan saudara orang tua dengan riwayat defek konotrunkal. Dari hasil studi case control di Atlanta ternyata faktor risiko tersebut tidak ada yang memiliki hubungan yang kuat menjadi faktor risiko terjadinya defek konotrunkal kecuali peningkatan risiko pada ibu yang diabetes dan saudara kandung yang memiliki defek konotrunkal dan stress saat hamil seperti kejadian kehilangan pekerjaan, perceraian atau perpisahan karena kematian teman atau keluarga. Namun konfirmasi mengenai stress masih memerlukan data lebih lanjut. ${ }^{7,8}$
Studi case control di California didapati bahwa wanita hamil yang minum alkohol kurang dari satu kali dalam seminggu selama masa awal kehamilan memiliki risiko 1.5 kali lebih besar dibandingkan yang tidak minum alkohol untuk melahirkan infan dengan defek konotrunkal jantung. (95\%CI:1.0,2.2). Namun penggunaan rokok selama masa kehamilan tidak memiliki hubungan yang signifikan dalam meningkatkan faktor risiko defek konotrunkal pada janin. ${ }^{9}$

Studi case control di Universitas Standford mengatakan bahwa faktor risiko asupan nutrisi masa kehamilan mempengaruhi kejadian defek konotrunkal. Namun data tidak menemukan adanya hubungan penurunan atau peningkatan risiko dengan asupan vitamin yang mengandung suplemen asam folat. Peningkatan risiko terjadinya TGA (defek konotrunkal) berhubungan dengan rendahnya asupan nutrisi yang mengandung asam linoleat, karbohidrat total, dan fruktosa. Sedangkan penurunan risiko TOF telah diobservasi untuk penurunan asupan adalah total protein dan metionin. Asupan yang rendah nutrisi yang mengandung folat, niacin, riboflavin dan vitamin B12, C, A dan E berhubungan dengan peningkatan risiko TGA bukan TOF. ${ }^{10}$

\section{Patofisiologi}

Perkembangan jantung yang abnormal menyebabkan beberapa defek jantung kongenital. Tabung jantung primitif berasal dari bagian yang paling lateral dari perkembangan jantung mesoderm dan sebagian besar naik ke ventrikel kiri. Kemudian saat jantung looping, saluran outflow memanjang dengan penambahan sel kardiogenik dari mesoderm splanik dan paringeal (sesuai dengan bidang jantung anterior dan sekunder secara berturut - turut). Mesoderm splanik dan paringeal berasal dari regio mediocaudal pembentukan jantung mesoderm dan kemudian menempati bagian anterior dari regio dorsal tabung jantung (rostrally). Oleh karena itu, progenitor jantung berperan pada regio saluran outflow yang dibedakan dari ventrikel kiri. ${ }^{11}$

Migrasi bidang jantung anterior (AHF) dibanding bidang jantung sekunder (SHF) pada saluran outflow dan perkembangan regio konotrunkal begitu juga sebagian dari ventrikel kanan mengingatkan kita bahwa migrasi yang abnormal pada AHF/SHF dapat menyebabkan malformasi konotrunkal. ${ }^{11}$ 


\section{Genetika Molekular}

Bukti menunjukkan bahwa mutasi dari gen CFC1, lokasi pada kromosom 2q memegang peranan pada etiologi DORV. Gen CFC1 mengkode anggota faktor pertumbuhan epidermal (EGF)- Cripto, Frl-1, danfamili Cryptic (CFC). Anggota protein famili EGF-CFC memberikan varian motif menyerupai EGF, sebuah domain yang kaya sistin dan regio $\mathrm{C}$ terminal yang bersifat hidrofobik. Anggota dari famili protein ini memegang peranan penting dalam alur signal interselular selama pembentukan embrio vertebra. Mutasi gen TBX1, berlokasi pada kromosom 22q1 telah dapat diidentifikasi pada kondisi heterozygot pasien dengan fenotip yang terkait dengan sindrom delesi $22 \mathrm{q} 11.2$ termasuk anomali konotrunkal sindroma wajah. Gen TBX1 merupakan anggota yang secara filogenetik dilestarikan keluarga gen yang berbagi domain ikatan DNA yaitu T - box. TBX1 menyeimbangkan proliferasi dan diferensiasi pada bidang anterior jantung/bidang sekunder jantung. Mutasi TBX1 menyebabkan dasar miokardium dari punggung pulmonal berkurang dan malposisi pada embrio saluran outflow. Gen T - box mengkode faktor transkripsi yang terlibat dalam regulasi dari proses organogenesis termasuk jantung. ${ }^{5,11}$

\section{Diagnosis}

Anomali konotrunkal dapat dideteksi pada masa kehidupan fetal dengan ekokardiografi yang memiliki tingkat akurasi yang tinggi. DSV luas dapat dideteksi dengan standar four chamber view pada pemeriksaan obstetrik inisial. Namun kelemahan dari pemeriksaan fetus adalah kesulitan untuk membuat orientasi arteri besar. Letak fetus, kualitas gambar dan umur gestasi akhir dapat memberikan kontribusi terjadinya kesalahan dalam diagnosis., 32

Menegakkan diagnosis defek konotrunkal menggunakan modalitas pengambilan gambar yang memberikan petunjuk yang tidak langsung untuk menegakkan diagnosis atau status klinis pasien. Beberapa teknik pencitraan modalitas antara lain: ${ }^{2}$

\section{Chest X - Ray (CXR)}

CXR merupakan teknik sederhana untuk pencitraan jantung. Siluet jantung abnormal dapat memberikan petunjuk pada klinisi. CXR sering digunakan untuk membantu pemantauan status kardiorespirasi secara umum dan komplikasi yang dapat muncul selama perawatan atau intervensi. Namun CXR sendiri saja tidak dapat menegakkan keputusan terhadap kasus penyakit jantung bawaan kompleks, seperti defek konotrunkal. ${ }^{2}$

\section{Ekokardiografi fetal}

Fetal ekokardiografi merupakan bidang yang luas untuk dasar pencitraan defek konotrunkal. Namun ibu yang hamil atau fetus yang telah diperkirakan memiliki risiko tinggi, banyak yang tidak menjalani ekokardiografi fetal. Dengan pemeriksaan four chamber view rutin saja tidak cukup untuk menilai defek pada fetal. Diperlukan investigasi pencitraan yang lebih detail untuk melihat traktus outflow dan arteri besar dan penggunaan doppler ultrasound. ${ }^{2}$

\section{Ekokardiografi tranthoraks}

Ekokardiografi transthoraks (TTE) merupakan modalitas pertama yang diaplikasikan pada bayi dengan kelainan jantung bawaan. TTE menjadi alat yang ideal dikarenakan mudah didapat, dapat dibawa dengan mudah, dan lebih aman (bersifat non radiasi) dan tidak invasif. Sesuai dengan umur pasien, pencitraan TTE bisa kurang baik dikarenakan jaringan parut, bentuk tubuh, atau penyebab lain dan lapangan pandang bisa terbatas. TTE adekuat untuk gambaran secara umum fungsi janrung tapi tidak detail. Banyak anak yang lebih tua membutuhkan modalitas pencitraan tambahan. ${ }^{2}$

\section{Ekokardiografi Tranesofageal}

TEE merupakan modalitas dengan invasif yang minimal dan dapat memberikan detail yang baik mengenai anatomis intrakardiak dan fungsi jantung, namun tidak sering digunakan pada anak yang sadar. TEE tidak sering digunakan untuk diagnosis atau pemantauan penyakit jantung bawaan. Namun sering digunakan pada setting operatifsaat perbaikan defek konotrunkal untuk menilai perbaikan yang adekuat dan untuk menentukan apakah terdapat defek signifikan yang cukup untuk dilakukan operasi yang lebih jauh sebelum menyelesaikan prosedur operasi. ${ }^{2}$

\section{Kateterisasasi kardiak dan angiografi}

Kateterisasi jantung menggunakan teknik yang akurat untuk menilai resistensi vaskular paru, yang 
tidak dapat dinilai pada pemeriksaan noninvasif. Kateterisasi dapat dipertimbangkan jika pasien baru pertama kali didiagnosis dengan defek konotrunkal yang signifikan pada masa infan. Modalitas ini dapat membantu menilai anatomi arteri koronaira dan anomali vaskular ekstrakardiak anomalous kecil yang sulit untuk diidentifikasi. Kateterisasi menjadi alat yang bernilai untuk memberikan informasi fisiologis ketika hasil pemeriksaan secara fisik tidak konsisten dengan diagnosisnya. ${ }^{2}$

\section{Cardiac Magnetic Resonance}

CMR merupakan modalitas pencitraan tiga dimensi yang tidak invasif, tidak radiasi dan memberikan informasi mengenai struktur dan fungsi jantung secara detail termasuk hubungan anatomis, volume ventrikel dan fungsinya, aliran permbuluh darah dan runagan, perfusi miokard dan viabilitas dan karakteristik jaringan. Agen kontras disebut gadolinium aman untuk anak. CMR dipertimbangkan sebagai gold standard untuk analisis volume ventrikular pada pasien dewasa. Pada pasien dengan defek konotrunkal, CMR menawarkan informasi tiga dimensi (3D) yang diperlukan untuk menentukan tindakan operasi yang sesuai untuk pasien dengan defek kompleks seperti pilihan untuk memperbaiki dua ventrikel atau melakukan operasi seri ventrikel tunggal secara paliatif. CMR juga dapat menentukan waktu yang optimal untuk mengulang tindakan operasi, seperti penempatan katup pulmonal pada pasien $\mathrm{TOF}^{2}$

\section{Cardiac Computed Tomography}

CCT memiliki kemampuan seperti CMR, menyediakan pencitraan 3D dan noninvasif. Resolusi spasial submilimeter memungkinkan dikarenakan peningkatan kecepatan dan resolusi dengan tomografi komputer multidetektor selama 10 tahun terakhir. Pemeriksaan ini memiliki keterbatasan antara lain saat prosedur dengan boluskontras, pasien harus dapat menahan nafas untuk waktu dilakukan skanning, sedangkan pasien yang lebih muda harus dilakukan pemberian sedasi. Walaupun pengetahuan dan pengalaman dengan CMR dan CCT menjadi luas, tapi tidak semua senter memiliki akses untuk teknologi ini atau untuk individu yang dapat melakukan ekspertise. ${ }^{2}$

Saat ini telah berkembang modalitas berupa Electron Beam CT untuk mengevaluasi anomali konotrunkal pada pasien anak dan dewasa. Modalitas ini memiliki keuntungan melebihi ekokardiografi dan pencitraan MR (Magnetic Resonance). Keuntungan termasuk waktu skaning yang singkat $(50-400 \mathrm{msec})$, temporal tinggi dan resolusi spasial dan memberikan gambaran ruang jantung dan pembuluh darah mediastinum dan dinding jantung. Teknik ini berguna khususnya pada anak dengan usia yang lebih muda tanpa dibutuhkan sedasi yang dalam. ${ }^{13}$

\section{Tatalaksana}

Terapi saat ini diperlukan pada defek konotrunkal adalah terapi operatif. Namun tingkat kematiannya sangatlah tinggi, apalagi defek konotrunkal dengan delesi kromosom 22q11 dan sindrom down. Beberapa tahun ini terjadi perkembangan kemampuan bedah jantung anak untuk menangani malformasi jantung kompleks yang mengubah hasil dari tipe defek jantung ini. Sehingga adanya tambahan sindroma genetik atau malformasi ekstrakardiak masih menjadi tantangan ahli jantung anak dan ahli bedah jantung anak sejak faktor ini dapat mempengaruhi perjalanan klinis dan akhir hasil tindakan pembedahan.

Studi mengatakan bahwa tingkat risiko yang kematian yang tinggi saat pembedahan tidak ada perbedaan yang signifikan pada pasien yang memiliki sindroma dan tidak, namun hal ini meningkat pada anak dengan delesi 22q11. Anak dengan delesi 22q11 bersamaan dengan adanya fenotip jantung yang parah termasuk arteri pulmonal yang tidak tersambung, kolateral aortapulmonal dan hiperesponsif saluran nafas yang persisten dapat memberikan komplikasi pada terapi operasi. Obstruksi saluran nafas dikarenakan cincin vaskular atau web laring dan tidak stabilnya vasomotor menjadi lanjutan komplikasi setelah operasi. Lebih lanjut lagi tendensi infeksi yang serius, khususnya jamur dapat meningkatkan mortalitas. ${ }^{2}$

\section{Prognosis}

Pada studi prognosis fetus dengan kelainan konotrunkal adalah buruk. Secara keseluruhan, 64\% (39/61) pada fetus dengan diagnosis prenatal anomali konotrunkal meninggal, termasuk terminasi elektif. Beberapa kehamilan dilanjutkan, 52\% (22/42) bertahan hidup selama 28 hari, tapi menurun sampai 41\% (17/41) pada saat umur 1 tahun. Mortalitas fetus dengan anomali konotrunkal berkisar dari 50\% sampai $65 \% .^{3}$ 
Prognosis pada fetus dengan kromosom yang abnormal atau terdapat anomali ekstrakardiak lebih buruk dibandingkan dengan fetus yang tidak. Mortalitas akhir sebelum umur 28 hari kehidupan kecuali terminasi elektif. Pada fetus dengan sangkaan anomali konotrunkal dan kelainan kromosom atau anomali yang besar ekstrakardiak, adalah 59\% dibandingkan $40 \%$ dari fetus yang tidak memiliki anomali. ${ }^{3}$

\section{Ringkasan}

Defek konotrunkal jantung adalah penyakit jantung kongenital yang melibatkan saluran outflow dari jantung dan pembuluh darah besar. Diagnosis prenatal dapat dilakukan dengan teknik ekokardiografi fetal. Defek ini berhubungan dengan delesi kromosom 22q11. Defek konotrunkal dengan delesi kromosom 22q11 memiliki prognosis dan tingkat mortalitas tindakan operatif yang buruk.

\section{Daftar Pustaka}

1. Lammer EJ, Chak JS, Lovannisci DM, Schutlz K, Osoegawa $\mathrm{K}$, yang $\mathrm{W}$ et al. Chromosomal abnormalities among children born with conotruncal cardiac defectts. Birth defects res a clin mol teratol.2009;85(1):30-5.

2. Jhonson TR. Conotruncal cardiac defects: a clinical imaging perspective. Pediatr cardiol.2010;31:430-7.

3. Tometzki AJP, Suda K, Kohl T, Kovalchin JP, Silverman NH. Accuracy of prenatal echocardiographic diagnosis and prog- nosis of fetuses with conotruncal anomalies. J am coll cardiol. 1999;33:1696-701.

4. Xu JY, Wang J, Xu R, Zhao PJ, Wang XK, Sun JH et al. Detecting 22q11.2 deletion in chinese children with conotruncal heart defect and single nucleotide polymorphisms in the haploid TBX1 locus. BMC medical genetics.2011;12:169.

5. Nair P, Tadmouri GO, Ali SA. Conotruncal heart malformation. Center for arab genomic studies.2011.1-2

6. Anaclerio S, Ciommo VD, Michielon G, Digiolio MC, Formigari R, Picchio FM et al. Conotruncal heart defects: impact of genetic syndromes on immediate operative mortality. Ital Heart J.2004;5(8):624-8.

7. Adams MM, Mulinare J, dooley K. Risk factors for conotruncal cardiac defect in atlanta. J am coll cardiol. 1989;14:432-42.

8. Lacro RV.Nadas' pediatric cardiologi. Dalam: Keane JF, Lock JE, Fyler DC, penyunting. Dysmofphology and Genetics. Edisi 6. Massachusets. Elsevier. 2006. H. 49 - 61.

9. Grewal J, Carmichael SL, Ma C, Lammer EJ, Shaw GM. Maternal periconceptional smoking and alcohol consumption and risk for select congenital anomalies. Birth defects res a clin mol teratol. 2008;82(7):519-26.

10. Shaw Gm, Carmichael SL, Yang W and Lammer JE. Periconceptional nutrient intakes and risks of conotruncal heart defects. Birth defects res a clin mol teratol. 2010;88(3):144-51.

11. Nakajiwa Y. Second lineage of heart forming region provides new understanding of conotruncal heart defects. Congenital anomalies. 2010;50:8-14.

12. Valdes LM and Gayre RO. Echocardiographic diagnosis of congenital heart disease. Dalam: cruz LM, Cayre RO, penyunting. Truncus arteriosus. Philadelphia. Lippincott. 2006.449-57.

13. Choi BW, Park YH, Choi JY, Choi BI, Kim MJ, Ryu SJ et al. Using electron beam ct to evaluate conotruncal anomalies in pediatric and adult patients. AJR. 2001;177:1045-49. 